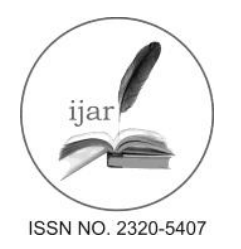

\author{
Journal homepage:http://www.journalijar.com \\ Journal DOI:10.21474/IJAR01
}

INTERNATIONAL JOURNAL

OF ADVANCED RESEARCH

RESEARCH ARTICLE

\title{
Isolation, Characterization and Optimization of Azo Dye Degrading Bacteria and Its Application In Textile Industry.
}

\author{
Sneh Lata*, Hardeep Kaur ${ }^{1}$ \\ Department of Biotechnology Chandigarh University, Gharuan.
}

\section{Manuscript Info}

Manuscript History:

Received: 14 March 2016

Final Accepted: 26 April 2016

Published Online: May 2016

Key words:

Methyl Orange, Decolorization,

Urease, Citrate hydrolysis. Nitrate reduction

*Corresponding Author

Sneh Lata

\begin{abstract}
Soil enriched with dye from Textile industry (Baddi) Dupatta house, Nalagarh, Dupatta staining house, Baddi Textile industry, kharuni, Nalagarh was taken. Isolation of bacteria from different soil samples was done. Morphological Characterization of isolates was done with the help of Gram Staining. Biochemical characterization of isolates was reported with the help of Indole, Methyl red, Catalase, Nitrogen reductase \& Urease, Citrate Hydrolysis, Hydrogen sulfide test. $\gamma / \max$ of methyl orange dye was determined. Optimization of the decolonization condition was done by optimizing its $\mathrm{pH} \&$ temperature as well as rate of Decolourization of methyl orange dye was determined. Screening of the most efficient bacterial strain for dye decolourizaion was done with the help of Nitrate reduction test This test is based on the detection of nitrite and its ability to form red color compound when it reacts with sulfanilic acid (Reagent A) to form a complex (Nitrite-sulfanilic acid) which then reacts with $\alpha$-Naphthylamine (Reagent B) to five red precipitates (prontosil).
\end{abstract}

Copy Right, IJAR, 2016,. All rights reserved.

\section{Introduction:-}

Dyes are colored \& aromatic compounds which show an affinity towards the substrate to which it is being applied. Most of the dyes are persistent environmental pollutants that are not removed from industrial effluents by conventional treatments (1).Tough controls are being applied to remove dyes from industrial effluents(2).there are many different types of dyes, but all of these,the azo aromatic ones are the most widespread dyes in the industry(3).Among azo dyes methyl orange is an important dye. It is prepared by coupling diazotized sulphanilic acid with dimethylaniline.It releases toxic \& carcinogenic products in the environment (4).The bacterial degradation is much faster than fungal degradation (5).Many bacteria,actinomycetes,yeast \& fungi are able to decolorize dyes (6).Lactobacillus casei TISTR 1500 from soli is selected as the most active azo dye degrader (7).Methyl orange was used to understand the mechanism of biodegradation by Pseudomonas sp.SUK1(8). Titanium dioxide showed higher activity for degrading the methyl orange(9) The azo dyes and their degradation intermediates such as aromatic amines are mutagenic and carcinogenic (10).

Therefore considerable attention has been given to evaluating the fate of azo dyes during waste water treatment and in the natural environment (11). Their widespread use ,coupled with the fact that azo dyes are not readily degraded in most biological treatment systems makes this class of chemicals a significant environmental problem(12). Removal of dyes from these wastewaters has been reviewed with respect to biological decolourization as well as complete biodegradation of the dyes molecules(13).

\section{Material and Methods:- Collection of soil sample:-}


To isolate methyl orange dye degrading bacteria the soil samples were collected from different locations preferably nearby textile industries located in and around Baddi, Distt. Solan (H.P). $5 \mathrm{~g}$ of soil was collected from each location.

\begin{tabular}{|c|c|c|}
\hline S.No. & Description & Location \\
\hline 1 & Soil enriched with dye & Textile industry(Baddi) \\
\hline 2 & & Dupatta House(Nalagarh) \\
\hline 3 & & Dupatta staining house(Baddi) \\
\hline 4 & & Textile industry (Nalagarh) \\
\hline
\end{tabular}

\section{Isolation of bacteria from different soil samples:-}

It was carried out by serial dilution agar-plate method. In this method a known amount (1g) of soil sample was suspended in a known volume $(10 \mathrm{ml})$ of sterile or saline water to make microbial suspension. Serial dilutions $10^{2}, 10^{3}, \ldots \ldots .10^{-7}$ was made by pipetting measured volumes (usually $1 \mathrm{ml}$ ) into additional dilution blanks (having 9 $\mathrm{ml}$ sterile/saline water). The contents of tubes were mixed by rolling the tube back and forth between hands for uniform distribution of organisms. From the first dilution, $1 \mathrm{ml}$ of suspension was transferred to the dilution blank $10^{-2}$ with a sterile $1 \mathrm{ml}$ pipette. The procedure was repeated until the original sample has been diluted $10^{-7}$ times. Poured autoclaved agar medium (supplemented with dye) to 7 Petri dishes and allowed the plates to solidify. $0.1 \mathrm{ml}$ of suspension was transferred to Petri dishes from each dilution and spread with the spreader. These plates were incubated in an inverted position for $24-48$ hours at $37^{\circ} \mathrm{C}$. Streaking (quadrant) was done on the nutrient agar plates for isolation of pure microbial strains.

\section{Morphological Characterization of isolates:-}

After growth the bacterial colonies which appeared on the medium were examined for morphological characterization. Gram staining was performed on each isolate to determine the shape of cells and to know the type of isolate (14)

Biochemical characterization of isolates:- Bacterial isolates were biochemically characterized by Indole, Methyl red,Voges ,Catalase, \& Hydrogen sulfide test (Berges Manual ,2010)

$\gamma /$ max of methyl orange dye: Maximum wavelength $\left(\gamma_{\max }\right)$ of methyl orange dye was obtained by observing 1 ppm dye in UV-VIS spectrophotometer

\section{Screening of bacterial strains for their Decolourization ability against Methyl orange:-}

$50 \mathrm{ppm}$ of Methyl orange dye was added to nutrient broth .The above solution was inoculated with different bacterial strains with help of sterilized loop and incubated at $37^{\circ} \mathrm{C}$ for 24 hours. Observed absorbance (OD) of Methyl orange dye at its $\gamma_{\max }$.

\section{$\%$ decolorization $=\mathrm{C}-\mathrm{T} / \mathrm{C}^{*} 100$}

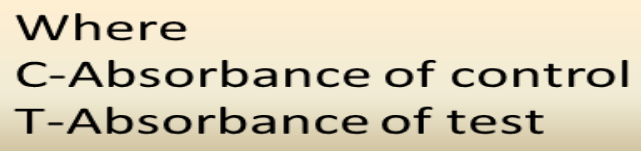

Optimization of the Decolourization condition:-It includes $\mathrm{pH}$ optimization \& Temperature optimization.

\section{pH optimization:-}

Nutrient broth was prepared and $100 \mathrm{ml}$ was added to each beaker. The $\mathrm{pH}$ of the broth was set at in the range of 1.0 -11.0 and labeled the flask according to the $\mathrm{pH}$. Transferred the broth from the beakers to the test and control flask in equal amount, add $0.005 \mathrm{~g}$ methyl orange azo dye in each flask and autoclaved. After cooling the flasks they were inoculated with most efficient bacterial strains and incubated at $37^{\circ} \mathrm{C}$ for $48 \mathrm{hrs}$. The dye decolourizaion was observed for bacterial strain at the lamda max of dye. Final $\mathrm{pH}$ was also recorded.

\section{Temperature optimization:-}


Nutrient broth was prepared ( $\mathrm{pH}$ 6.0). The flasks were labeled with temperature as $25^{\circ} \mathrm{C}, 30^{\circ} \mathrm{C}, 37^{\circ} \mathrm{C}, 40^{\circ} \mathrm{C}$ and $45^{\circ}$ $\mathrm{C}$ for both test and control flasks. Transferred $100 \mathrm{ml}$ of broth into each flask, Added 0.005g Methyl Orange azo dye into each flask and autoclaved these. Inoculated the test flasks with bacterial strain and then incubated at respective temperatures for $48 \mathrm{hrs}$. After that, dye decolourizaion was observed at the lamda max of dye.

Rate of Decolourization of methyl orange dye:- Rate of Decolourization was calculated using the formula:

Decolourization rate $=\mathrm{C} \%$ Decolourization $/ \mathbf{1 0 0 t}(15)$.

Where $\mathrm{C}=$ Concentration of dye used $(\mathrm{mg} / \mathrm{l})$

$\mathrm{T}=$ Time $(\mathrm{h})$

\section{Results and Discussion:-}

We isolated eight different strains \& named them as DPI,DPII-----DPVIII.

455.6nm lambda max was observed on UV-Visible spectrophotometer when 1ppm methyl orange dye was scan from $400 \mathrm{~nm}$ to $900 \mathrm{~nm}$.

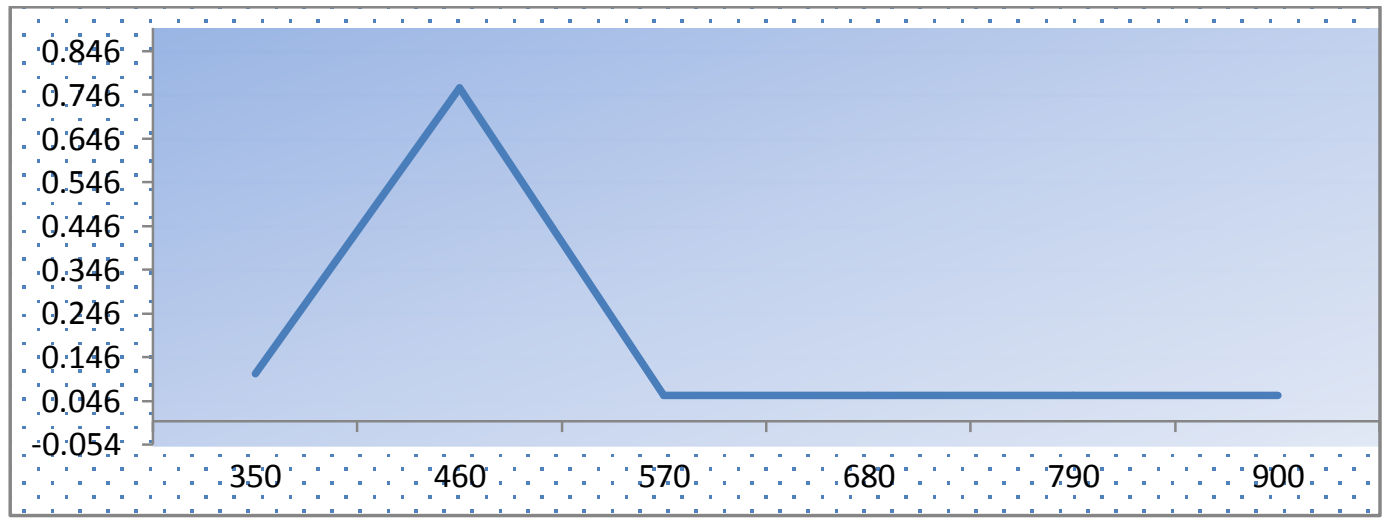

Figure 1:- 455.6nm lambda max was observed on UV-Visible spectrophotometer screening of the most efficient bacterial strain for dye Decolourization.

8 different isolates were then screened to get the best strain to show maximum decolourizaion of methyl orange. The percentage decolourizaion of bacterial strains was calculated after an incubation of 48 hours. It was observed that the strain designated as DP IV showed maximum decolourizaion of methyl orange within 48 hours i.e. $82.15 \%$ and the strain designated as DP VI showed minimum decolourizaion (9\%).In previous researches many azo dyes have been reported to be degraded by Bacillus species, Bacillus subtilisshowed $80 \%$ decolourization of disperse yellow 211 (16) However 100\% decolourizaion of golden yellow dye by Bacillus species. 98\% decolourizaion of an azo dye, remazol black B was shown by Paenibacillus species(17).

Table 1:- Showing percentage decolourization of Strains.

\begin{tabular}{|c|c|c|c|c|c|c|}
\hline \multirow[t]{2}{*}{ S.No. } & \multirow[t]{2}{*}{ Strain code } & \multirow{2}{*}{$\begin{array}{l}\text { Media } \\
+ \text { dye }\end{array}$} & Incubation & \multicolumn{2}{|c|}{ Absorbance after 48 hours } & \multirow[t]{2}{*}{$\%$ decolourization } \\
\hline & & & \multirow{7}{*}{$\begin{array}{l}\text { At } 37^{\circ} \mathrm{C} \text { for } \\
48 \text { hours }\end{array}$} & Control & Test & \\
\hline 1 & DP I & \multirow{6}{*}{$50 \mathrm{ml}$} & & 1.597 & 0.536 & $66.40 \%$ \\
\hline 2 & DP II & & & 1.597 & 0.748 & $53 \%$ \\
\hline 3 & DP III & & & 1.597 & 0.633 & $60 \%$ \\
\hline 4 & DP IV & & & 1.597 & 0.285 & $82 \%$ \\
\hline 5 & DP V & & & 1.597 & 0.965 & $39 \%$ \\
\hline 6 & DP VI & & & 1.597 & 1.451 & $09 \%$ \\
\hline 7 & DP VII & & & 1.597 & 1.405 & $12 \%$ \\
\hline 8 & DP VIII & & & 1.597 & 1.278 & $19 \%$ \\
\hline
\end{tabular}




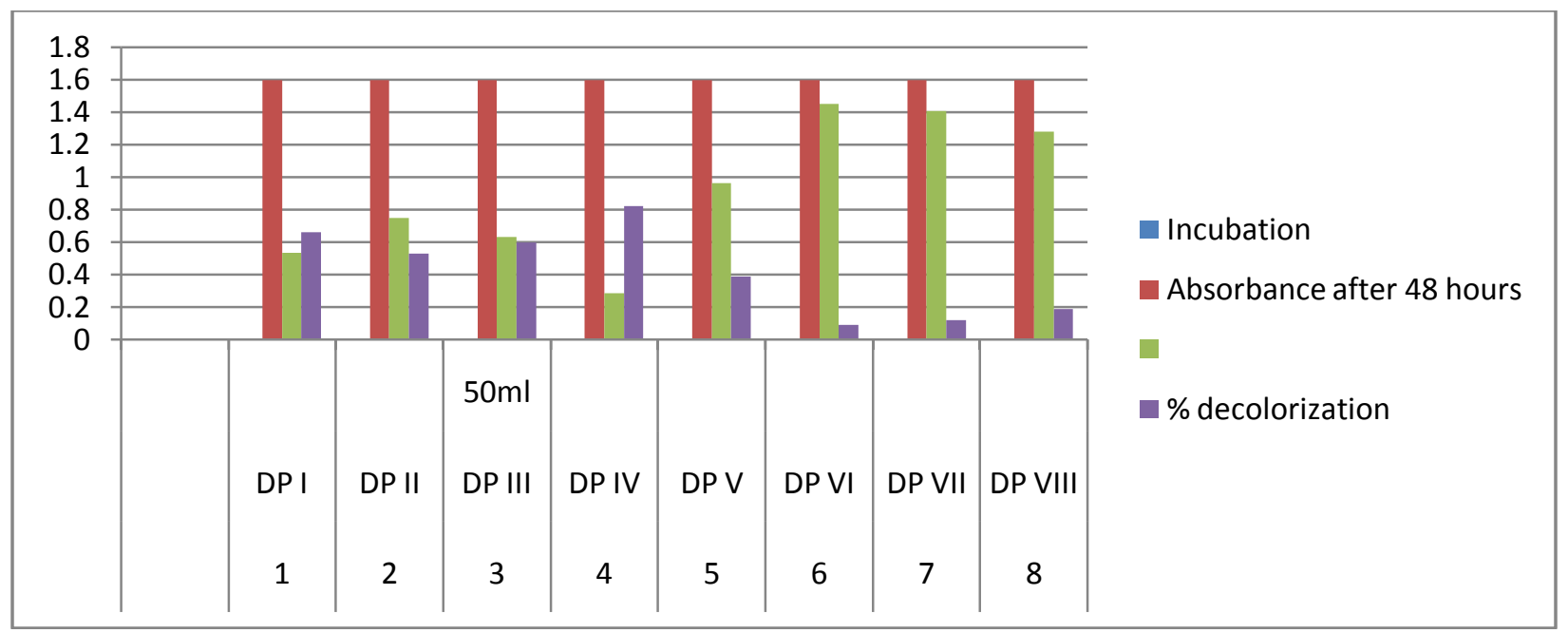

Figure 2:- Graphical presentation of percentage Decolourization of different strains Morphological Characterization of Bacterial Isolates:

TheGram staining method is a useful method for identifying \& classifying bacteria into two major groups. The bacterium which retains dark blue color is called Gram positive \& those that appear pink with counter stain safranin are referred as Gram Negative. The results of morphological characterization are as below in table.

Table 2:-Morphological Characterization of Bacterial Isolates.

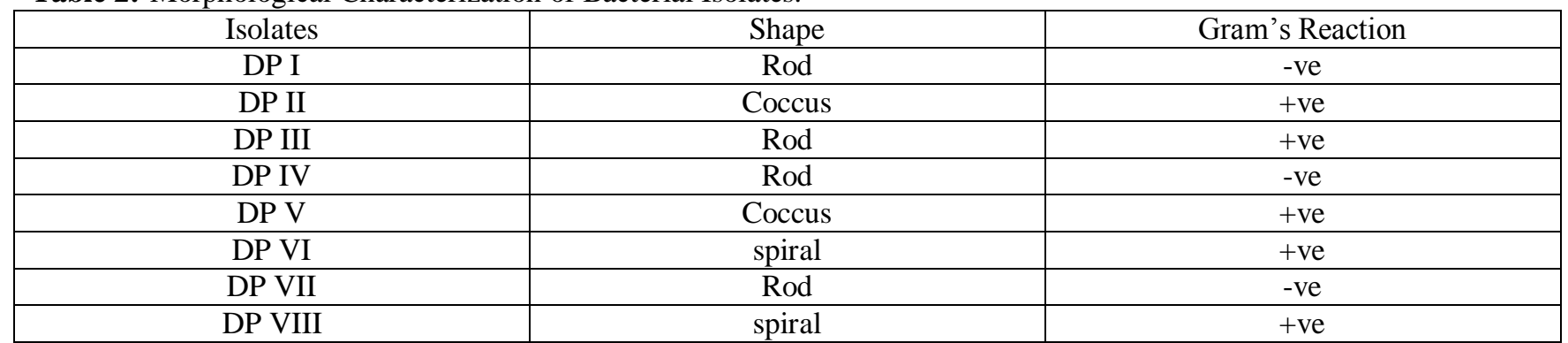

Biochemical Characterization of Bacterial Isolates: for further identification of bacterial isolates various biochemical tests were performed. Results are given below

Table 3:- Biochemical Characterization of Bacterial Isolates.

\begin{tabular}{|c|c|c|c|c|c|c|c|}
\hline Isolates & Indole test & Mr/vp test & Catalase test & Urease test & H2s test & Nitrate test & Citrate test \\
\hline DP I & -ve & $+\mathrm{ve} /-\mathrm{ve}$ & +ve & -ve & +ve & +ve & -ve \\
\hline DP II & -ve & -ve/+ve & -ve & $+\mathrm{ve}$ & $+\mathrm{ve}$ & $+\mathrm{ve}$ & -ve \\
\hline DP III & $+\mathrm{ve}$ & -ve/+ve & $+\mathrm{ve}$ & -ve & $+\mathrm{ve}$ & $+\mathrm{ve}$ & $+\mathrm{ve}$ \\
\hline DP IV & $+\mathrm{ve}$ & +ve/-ve & $+\mathrm{ve}$ & $+\mathrm{ve}$ & $+\mathrm{ve}$ & $+\mathrm{ve}$ & -ve \\
\hline DP V & $-\mathrm{ve}$ & -ve/+ve & -ve & +ve+ve & $-\mathrm{ve}$ & $+\mathrm{ve}$ & $+\mathrm{ve}$ \\
\hline DP VI & $+\mathrm{ve}$ & +ve/-ve & $+\mathrm{ve}$ & +ve & -ve & -ve & $+v e$ \\
\hline DP VII & -ve & +ve/-ve & $+\mathrm{ve}$ & -ve & -ve & +ve & -ve \\
\hline DP VIII & $+\mathrm{ve}$ & -ve/+ve & $+\mathrm{ve}$ & -ve & $+\mathrm{ve}$ & $+v e$ & -ve \\
\hline
\end{tabular}

Optimization of Decolourization conditions:-

DP IV the best degrader of Methyl Orange was subjected to optimization studies. The decolourization of Methyl Orange was found to be $87.13 \%$ at $\mathrm{pH}$ 6.0.100\% decolourization of methyl orange was observed at $\mathrm{pH}$ optimized at 6.8.(18).However $92 \%$ decolourization was observed by Bacillus cereusat pH 7.0 was observed (19) 


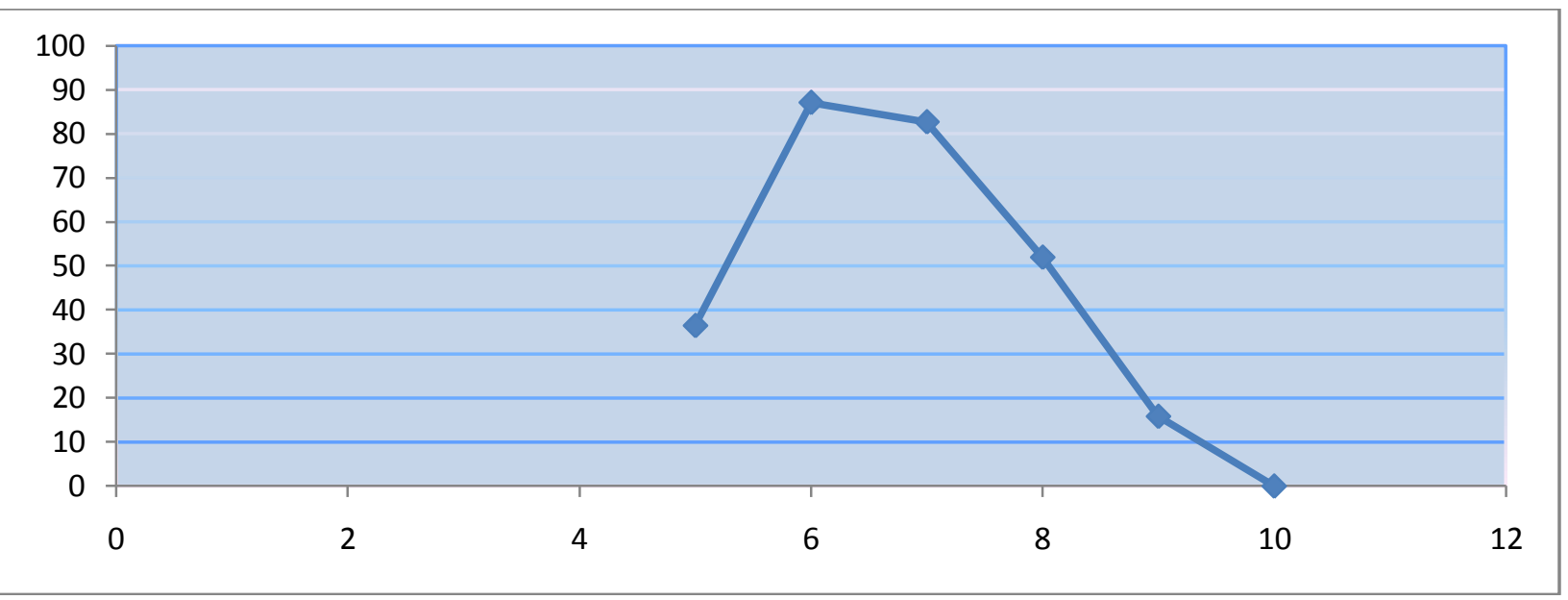

Figure 3:- pH Optimization.

Temperature Optimization: The maximum decolourization of methyl orange reached $94.23 \%$ at $37^{\circ} \mathrm{C}$ with $\mathrm{pH}$ 6.0.Another research showed decolourization of methyl orange by Bacillus sp.at $30^{\circ} \mathrm{C}(20)$. However maximum decolourization of methyl orange by Lactobacillus caseiat temperature optimized at $35{ }^{\circ} \mathrm{C}$

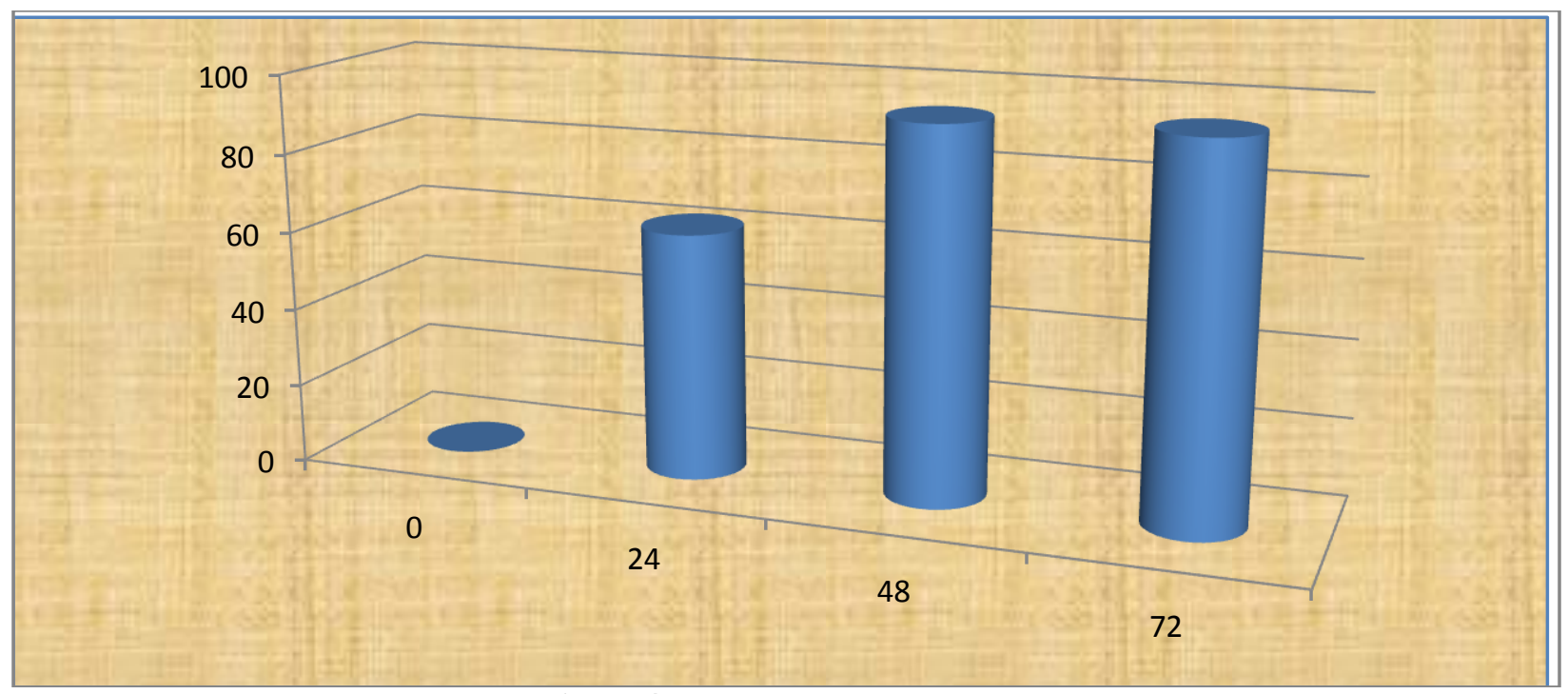

Figure 4:-Temperature Optimization

Rate of Decolourization of Methyl Orange Dye: As shown in table no.4

Table 4:-\%age Decolourization at different time intervals: as shown in table below

\begin{tabular}{|l|c|c|c|c|}
\hline S.No. & Incubation & \multicolumn{2}{|c|}{ Absorbance at 455.6nm } & \% Decolourization \\
\hline & & Control & Test & 0 \\
\hline 1 & 0 & 1.579 & 1.579 & 62.40 \\
\hline 2 & 24 & 1.589 & 0.589 & 94.23 \\
\hline 3 & 48 & 1.597 & 0.092 & 94.94 \\
\hline 4 & 72 & 1.623 & 0.082 & \\
\hline
\end{tabular}




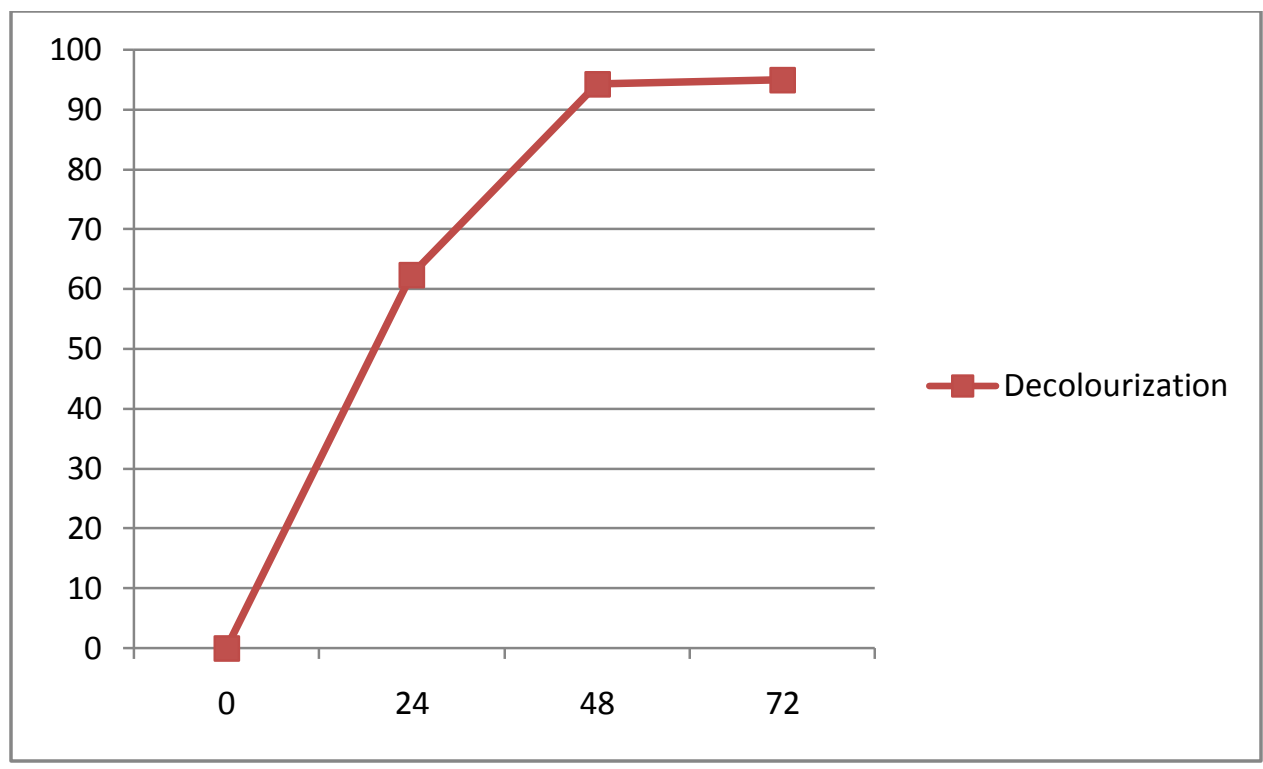

Figure 5:-Percentage Decolourization

The rate of Decolourization of methyl orange was calculated as $0.66 \mathrm{mg} / \mathrm{lt} / \mathrm{hr}$. Thus it is evident from cited results that Bacillus sp. could decolorize methyl orange approximately $94.94 \% \&$ temperature $37^{\circ} \mathrm{C}$ with decolorizing rate of $0.66 \mathrm{mg} / \mathrm{lt} / \mathrm{hr}$. thus can be used as a tool for decolourizaion \& further research with respect to its commercial application

\section{Conclusion:-}

Dyes are widely used in textile, rubberproduct; paper cosmetics\& many other industries, Methyl orange represent the largest \&most versatile class of synthetic dyes.Some of the dyes are harmful, dye containing wastes important environmental problem. These dyes are poorly biodegradable because of their structures\& treatment of wastewater contain dyes usually involves physical \& chemical methods such as adsorption, oxidation\& electrochemical methods. Pseudomonas sp.shows higher activity on dyes selected (21), this was the first time in which growth on textile dyes of these microorganisms was reported. Staphylococcus aretacould only decolorize the dyes effectively when the medium was supplemented with yeast extract (22)

\section{References:-}

1. Willmot,N.J., \& Nelson ,G.(1998) The biotechnology approach to colour removal from textile effulent.Journal of society of Dyers \& colourist .114:38-41.

2. Kuhad,R.C.\&Ward,O.P.(2004) Advances in applied microbiology. Journal of Microbiology 56:185-213.

3. Zille,\& Cavaco-Paullo,A.(2005).Journal of Applied \& Environmental Microbiology.71(11):6711-6718.

4. Meena I,V.K.(2010). Journal of Indian council of chemistry. 27(2):180-184

5. Sarbolouki.,Nabi,M.,Ali (2007) Metabolism of azo dyes by Lactobacillus CaesiTISTR 1500. Journal of water Resources. 41(5):985-992.

6. Katia M.G.,\&Rosa (2006).biodegradtion of reactive textile dyes by basidiomycetes fungus. Brazillian Journalof Microbiology . 37: 481-487

7. Seesuriyachan,P\& Aoki,K.(2007).Metabolism of azo dyes by Lactobacillus CaseiTISTR 1500. Journal of water research, 41(5):985-992.

8. Kalyani.,D.C(200 9) Biodegradation of reactive textile dye by isolated Pseudomonas sp..Journal of water Environment Resource .81 (3) :298-307

9. Ali,S.A.M.\& Abdullah.Sonocataytic degradation of methyl orange in effulent dye. International Conference on Environment \& Industrial Innovation.12:296-302

10. Elbanna,K., Hassan,G.,Khider,Mand Mandour,R.(2010).Biodegradation of textile azo dye by newly isolated lactic acid bacteria.Journal of Bioremediation and Biodegradation.1(3):50-72.

11. Tan (2001).Integrated and sequential anerobic /aerobic biodegradation of azo dye.Journal of Microbiology.374(8):1613-1618.

12. Bumpus,J.A.(1995).Progress in industrial Microbiology .Journal of microbiology(32):157-176. 
13. Rai ,H.S.,Bhattacharyya,M.S.,Singh(2005).Removal of dyes from effluent of textile and dyestuff manufacturing industry.Journal of Environmental science and Technology.35(3):219-238.

14. Aneja,K.R.(2002) Experiments in Microbiology, PlantPathology. New Delhi3:30-90.

15. Budhe,N.N.(2011) Journal of Microbiology .15(5) 203-210.

16. Parveen,S.,Lakhvinder,S.,(2009)Optimization of process variables for decolourization of disperse yellow 211 by Bacillus subtilis.Journal of Hazardous material 164:1024-1029.

17. Meehan,N.J,Kaushik(2001).Journal of water research 12(5): 123-127

18. Parshethi.G.K.,Telke,A.A(2010).Decolourization of methyl orange dye by Kocuria rosea. Journal of Hazardous material 176:503-509.

19. Ayed, L.Jannet ,H.B.,(2010) Response surface methodology for decolourization of methyl orange dye. Journal of chemical Engineering. 165(1): 200-208).

20. Sarbolouki.,Nabi,M.,Ali(2005) Metabolism of azo dyes by newly synthsiszed Bacillus sp.TISTR 1500. Journal of chemical Engineering. 24(5):41-45

21. Costa ,L.N. Journal of experimental Microbiology. 12(9) 402-407.

22. Chung,K.L.(2009) Degradation of azo dyes by environmental microorganisms. Journal of Environmental toxicology .12(11):2121-2132. 